\title{
Subacute ruminal acidosis challenge changed in situ degradability of feedstuffs in dairy goats
}

\author{
Fei Li, Yangchun Cao, Nannan Liu, Xinjian Yang, Junhu Yao, ${ }^{1}$ and Dabing Yan \\ College of Animal Science and Technology, Northwest A\&F University, Yangling, Shaanxi 712100, P. R. China
}

\begin{abstract}
This study investigated the effects of wheat-induced subacute ruminal acidosis (SARA) on rumen bacterial populations and in situ degradabilities of NDF, starch, and crude protein of feeds. Four multiparous dairy goats $(\mathrm{BW}=60 \pm 3.3 \mathrm{~kg})$ fitted with ruminal cannulas were assigned to a $2 \times 2$ crossover design (28-d treatment periods separated by a 7 -d washout interval). The treatment diets consisted of 2 levels of cracked wheat: 0 (control, corn based concentrate) and $35 \%$ (diet-induced SARA, wheat-based concentrate), with a constant forage- (45\% alfalfa hay and 5\% corn silage of DM) to-concentrate (50\% of DM) ratio. Results indicate that diets with a $35 \%$ wheat decreased ruminal $\mathrm{pH}(6.21$ vs. 5.98) and increased the duration $(1.13$ vs. $4.72 \mathrm{~h} / \mathrm{d})$ and area $(0.12$ vs. $0.78 \mathrm{pH} \times \mathrm{h} / \mathrm{d})$ of ruminal $\mathrm{pH}$ below 5.6 and induced SARA. The SARA increased ruminal total volatile fatty acid concentration, from 105.0 to $123.8 \mathrm{mM}$, and decreased the acetate molar proportion (62.8 vs. $56.6 \mathrm{~mol} / 100 \mathrm{~mol}$ ) and the acetate-to-propionate ratio (3.5 vs. 2.8). Compared with the control group, SARA decreases the relative abundance of Fibrobacter succinogenes $(-59.3 \%)$ and Ruminococcus flavefaciens $(-68.4 \%)$, whereas it increased Succinimonas amylolytica (198.1\%) and Ruminobacter amylophilus (125.2\%). The SARA decreased 24- and 48-h dry matter (DM) and neutral detergent fiber (NDF) degradabilities of corn silage. The 48-h degradabilities of DM (51.0 vs. $48.2 \%$ ) and NDF (40.3 vs. $36.0 \%$ ) in alfalfa hay were not affected by SARA, but the SARA tended to reduce the 24-h DM (49.6 vs. $46.3 \%$ ) and NDF (37.8 vs. $33.2 \%$ ) degradabilities. The effective ruminal degradabilities of DM and NDF in alfalfa hay and corn silage were reduced during SARA. In situ degradability parameters of DM and starch of wheat were not affected by SARA, but starch degradability of corn (9.5 vs. $13.3 \% / \mathrm{h})$ increased. The SARA reduced in situ 12-h degradabilities of DM and crude protein of soybean meal and extruded soybean with-
\end{abstract}

Received November 3, 2013.

Accepted May 2, 2014.

${ }^{1}$ Corresponding author: yaojunhu2004@sohu.com out affecting the degradabilities of the other protein supplements (corn gluten meal, cottonseed meal, corn dried distillers grains with solubles, rapeseed meal, and wheat germ meal). These results indicated that the cracked wheat-induced SARA reduced the degradation of NDF in roughages and that of protein in soybean meal $(-19.8 \%)$ and extruded soy $(-18.9 \%)$ and increased the starch degradability in corn, due to the increased amylolytic bacteria and decreased cellulolytic bacteria counts in the rumen.

Key words: in situ degradation, protein, starch, subacute ruminal acidosis

\section{INTRODUCTION}

Subacute ruminal acidosis is characterized by a long duration of low ruminal $\mathrm{pH}(\mathrm{pH}<5.6$ for more than $3 \mathrm{~h} / \mathrm{d}$; Gozho et al., 2005), and approximately $20 \%$ of high-yielding dairy herds experience SARA (Kleen and Cannizzo, 2012). Subacute ruminal acidosis reduces cellulolytic bacteria counts because of undesirable ruminal $\mathrm{pH}(<5.8$; Russell and Wilson, 1996), resulting in low fiber degradation. Plaizier et al. (2001) observed that SARA reduced in situ $48-\mathrm{h}$ DM $(-7 \%)$ and NDF $(-22 \%)$ degradabilities of mixed hay in dairy cows. Several studies reported that ruminants fed highly fermentable carbohydrate diets stimulated the proliferation of ruminal amylolytic bacteria (Goad et al., 1998; Fernando et al., 2010; Petri et al., 2012). With the possible exception of the main cellulolytic species (Fibrobacter succinogenes, Ruminococcus albus, and Ruminococcus flavefaciens), most rumen microorganisms (e.g., Butyrivibrio fibrisolvens, Bacteroides amylophilus, and Bacteroides ruminicola) are proteolytic (Hobson et al., 1982; Wallace, 1996), and ruminants consuming highgrain diets increased proteolytic activity (Furchtenicht and Broderick, 1987; Hristov et al., 2002). In contrast, Rotger et al. (2006) reported that the dietary forage-toconcentrate ratio had no effect on in situ CP degradation kinetics of 7 plant protein supplements in heifers.

The rate and extent of nutrient (starch, protein, and fiber) degradation in the rumen mainly depends on the complex enzymes system (polysaccharide and proteolytic enzymes) of ruminal microbiota and the struc- 
ture of substrates (McAllister et al., 1994; Wang and McAllister 2002; Bach et al., 2005). Factors affecting fiber degradation during SARA have been well studied (Krajcarski-Hunt et al. 2002; Plaizier et al. 2008). However, the interactions between the ruminal amylolytic and cellulolytic bacteria on starch and protein degradation were seldom estimated in the current feed evaluation systems (Bannink and Tamminga, 2005). Data on the effect of SARA on the degradation of starch and protein in the rumen is limited. Therefore, it was hypothesized that SARA might affect the rumen degradation of fiber, starch, and protein in feeds by changing the ruminal bacteria population (increase in amylolytic species and decrease in cellulolytic species). The objective of the current study was to estimate the effect of wheat-induced SARA on ruminal amylolytic and cellulolytic species, and in situ degradability of NDF (in roughages), starch (in grains), and CP (protein supplements) in dairy goats.

\section{MATERIALS AND METHODS}

\section{Animals, Diets, and Experimental Design}

All experimental procedures were approved by the Northwest A\&F University Animal Care and Use Committee of P. R. China. Four multiparous Xinong Saanen dairy goats $(\mathrm{BW}=60 \pm 3.3 \mathrm{~kg})$ fitted with ruminal cannulas were randomly divided into 2 groups (each with 2 goats) according to a $2 \times 2$ crossover design. Treatment diets consisted of 2 levels of cracked wheat: 0 (1; control) and $35 \%$ (2; diet-induced SARA) of dietary DM (Table 1). Goats in group 1 received the control diet and goats in group 2 received the SARA diet in period 1. Goats switched diets in the second period after a 7-d washout period during which all goats were fed the control diet to avoid carryover effects of the SARA diet. Contents of starch and CP in the diet were similar between the treatments. Diets were composed of alfalfa hay $(45 \%$ of DM), corn silage $(5 \%$ of DM), and concentrate $(50 \%$ of DM). Each experimental period lasted for $28 \mathrm{~d}$, with $18 \mathrm{~d}$ for adaptation to the diet and $10 \mathrm{~d}$ for sample collection, in situ degradation assay, and $\mathrm{pH}$ measurements. Goats were housed in individual metabolism cages $(1.5 \times 0.7 \mathrm{~m})$ and fed twice daily, at 0700 and $1900 \mathrm{~h}$, on an ad libitum basis (allowing for $5-10 \%$ orts) with free access to fresh water throughout the experiment.

\section{Sample Collection and $\mathrm{pH}$ Measurement}

Ruminal pH was continuously monitored for $24 \mathrm{~h}$, from $0700 \mathrm{~h}$ on $\mathrm{d} 19$ to $0700 \mathrm{~h}$ to $\mathrm{d} 20$. The ruminal $\mathrm{pH}$ was measured using an industrial electrode linked to a
$\mathrm{pH}$ transmitter and a data logger was used to record data as described in detail by Zhao et al. (2011). Data of ruminal $\mathrm{pH}$ were measured at 30-s intervals and averaged every 5 min. The data were summarized across $24 \mathrm{~h}$ for each goat as mean, area (time $\times \mathrm{pH})$, and time under $\mathrm{pH} 5.8$ or 5.6 .

Approximately $100 \mathrm{~mL}$ of ruminal fluid was obtained of each goat from the ventral rumen sac at 0700 (before feed delivery), 1000, 1300, 1600, and $1900 \mathrm{~h}$ on d 20 and strained through 2-layer cheesecloth. Four milliliters of filtrate were mixed with $1 \mathrm{~mL}$ of $25 \%$ (wt/vol) metaphosphoric acid and stored at $-40^{\circ} \mathrm{C}$ for analysis of VFA. To extract microbial genomic DNA, samples of rumen content (about $200 \mathrm{~g}$ ) of each goat were also obtained at each sample time and stored at $-80^{\circ} \mathrm{C}$.

\section{In Situ Degradation Procedure}

Feedstuffs for in situ incubation were dried at $60^{\circ} \mathrm{C}$ for $48 \mathrm{~h}$ and grounded through a $2-\mathrm{mm}$ screen. The chemical composition of the test feeds is presented in Table 2. A portion of each feedstuff ( $2 \mathrm{~g}$ for roughage, $4 \mathrm{~g}$ for grain, and $5 \mathrm{~g}$ for protein supplement) was weighed into respective nylon bags $(7 \times 10 \mathrm{~cm}, 53-\mu \mathrm{m}$ pore size) and sealed by suture. Bags were soaked in warm water $\left(39^{\circ} \mathrm{C}\right)$ for 10 min before being inserted into the rumen. In situ degradation was sequentially determined in roughages (alfalfa hay and corn silage),

Table 1. Ingredients and composition of the diets

\begin{tabular}{|c|c|c|}
\hline Item, $\%$ of DM & Control & $\begin{array}{c}\text { Subacute } \\
\text { ruminal } \\
\text { acidosis }\end{array}$ \\
\hline \multicolumn{3}{|l|}{ Ingredient } \\
\hline Alfalfa hay & 45 & 45 \\
\hline Corn silage & 5 & 5 \\
\hline Corn & 40 & 7 \\
\hline Wheat & - & 35 \\
\hline Wheat bran & - & 4.25 \\
\hline Soybean meal & 7.5 & 0.75 \\
\hline Calcium phosphate & 0.25 & 0.25 \\
\hline Limestone & 0.75 & 0.75 \\
\hline Corn oil & - & 1 \\
\hline Urea & 0.5 & - \\
\hline Salt & 0.5 & 0.5 \\
\hline Vitamin-mineral mix ${ }^{1}$ & 0.5 & 0.5 \\
\hline \multicolumn{3}{|l|}{ Nutrient composition } \\
\hline DM & 85.7 & 87.1 \\
\hline NDF & 34.3 & 35.7 \\
\hline $\mathrm{ADF}$ & 21.7 & 22.3 \\
\hline Forage NDF & 28.5 & 28.5 \\
\hline $\mathrm{CP}$ & 15.2 & 15.3 \\
\hline Starch & 28.9 & 29.2 \\
\hline
\end{tabular}

${ }^{1}$ Vitamin-mineral mix (per kilogram, DP104, Wangduofu Biotech Co. Ltd., Yangling, China): 1,000 $\mathrm{mg}$ of nicotinic acid, $800 \mathrm{mg}$ of $\mathrm{Mn}$, $1,800 \mathrm{mg}$ of $\mathrm{Zn}, 2,200 \mathrm{mg}$ of Fe, $370 \mathrm{mg}$ of $\mathrm{Cu}, 30 \mathrm{mg}$ of Se, $30 \mathrm{mg}$ of I, $50 \mathrm{mg}$ of Co, 6,500 IU of vitamin E, 4,500 IU of vitamin $\mathrm{D}_{3}$, and 200,000 IU of vitamin A. 
Table 2. Chemical composition of in situ incubation feedstuffs

\begin{tabular}{lccccr}
\hline Feedstuff, ${ }^{1} \%$ of DM & DM & CP & NDF & Starch & Ash \\
\hline Corn & 96.6 & 8.3 & 10.4 & 63.3 & 1.6 \\
Wheat & 95.8 & 14.5 & 13.1 & 59.1 & 2.3 \\
Alfalfa hay & 92.5 & 12.2 & 66.8 & - & 10.2 \\
Corn silage & 93.2 & 10.8 & 66.0 & - & 5.5 \\
Corn gluten meal & 96.2 & 66.9 & 13.2 & - & 3.7 \\
Cottonseed meal & 95.1 & 50.5 & 26.3 & - & 6.2 \\
Dried distillers grains with solubles & 94.4 & 31.8 & 32.2 & - & 6.3 \\
Extruded soybean & 97.4 & 36.9 & 21.0 & - & 8.9 \\
Rapeseed meal & 95.8 & 40.1 & 35.3 & - & 7.5 \\
Soybean meal & 95.1 & 46.6 & 14.7 & - & 2.3 \\
Wheat germ meal & 96.1 & 33.0 & 28.9 & & \\
\hline
\end{tabular}

${ }^{1}$ These feedstuffs were dried in an oven at $60^{\circ} \mathrm{C}$ for $48 \mathrm{~h}$ before incubating in rumen.

grains (corn and wheat), and plant protein supplements (rapeseed meal, corn gluten meal, cottonseed meal, corn dried distillers grains with solubles, extruded soy, soybean meal, or wheat germ meal) from d 21 (0700 h) to $26(1900 \mathrm{~h})$. Bags with grain feeds were incubated in the rumen for 0 (water washed), 2, 4, 8, 16, 32, and $48 \mathrm{~h}$. Similarly, bags with roughage were incubated for $0,3,6,12,24,48$, and $72 \mathrm{~h}$. All bags with protein supplements were incubated for $12 \mathrm{~h}$. All time points were incubated in duplicate. At each time point, 2 bags were removed from each goat and washed under cold tap water until the effluent water remained clear.

\section{Chemical Analyses}

Gas Chromatography Analysis. Thawed rumen fluid samples were centrifuged for 15 min at 19,000 $\times g$ at $4^{\circ} \mathrm{C}$. A sample of $2 \mathrm{~mL}$ of supernatant was mixed with $200 \mu \mathrm{L}$ of crotonic acid (1\% wt/vol; internal standard) and then filtered through a $0.22-\mu \mathrm{m}$ filter. Concentrations of ruminal VFA were separated and quantified by gas chromatography (Agilent Technologies 7820 GC system) using a $30-\mathrm{m} \times 0.25-\mathrm{mm} \times 0.33-\mu \mathrm{m}$ fused silica column (AE-FFAP, Atech Technologies Co. Ltd., Lanzhou, China). The injector and detector temperatures were set at 200 and $250^{\circ} \mathrm{C}$, respectively. The column temperature was increased from 45 to $150^{\circ} \mathrm{C}$ at $20^{\circ} \mathrm{C} /$ min and held for 5 min.
Microbial DNA Extraction and Quantitative Real-Time PCR. Total microbial genomic DNA was extracted from rumen content samples using an E.Z.N.A. Stool DNA Kit (Omega Bio-Tek, Norcross, GA) following the manufacturer's instructions. The method included a bead-beating step for the mechanical lysis of the microbial cells. The quantitative real-time PCR (qPCR) primers of bacteria (F. succinogenes, $R c$. flavefaciens, Rc. albus, Streptococcus bovis, Ruminobacter amylophilus, and Succinimonas amylolytica, and general bacteria) used are listed in Table 3. The qPCR assays were performed on a Bio-Rad iQ5 multicolor Real-Time PCR Detection System (Bio-Rad Laboratories, Hercules, CA), and the $\mathrm{qPCR}$ program and chemicals used were described as Zhao et al. (2013). The relative population abundances of specific bacteria were expressed as the percentage of total bacterial $16 \mathrm{~S}$ rRNA gene (Denman and McSweeney, 2005).

Starch, NDF, and CP Degradation. After rinsing, all bags were dried in a forced-air oven at $60^{\circ} \mathrm{C}$ for $72 \mathrm{~h}$ to determine DM. For corn and wheat samples, the residual starch content in the bag was determined by an enzymatic method ( $\alpha$-amylase and amyloglucosidase) with a commercial starch analysis kit (Megazyme, Megazyme International Ireland Ltd., Bray, Ireland). For alfalfa hay and corn silage, the residual NDF in the bag was determined according to the method described by Van Soest et al. (1991), with heat stable $\alpha$-amylase

Table 3. The PCR primers for amplifying target populations

\begin{tabular}{lll}
\hline Target species $^{1}$ & Forward primer & Reverse primer \\
\hline General bacteria & CGGCAACGAGCGCAACCC & CCATTGTAGCACGTGTGTAGCC \\
Fibrobacter succinogenes & GTTCGGAATTACTGGGCGTAAA & CGCCTGCCCCTGAACTATC \\
Ruminococcus flavefaciens & CGAACGGAGATAATTTGAGTTTACTTAGG & CGGTCTCTGTATGTTATGAGGTATTACC \\
Ruminococcus albus & CCCTAAAAGCAGTCTAGTTCG & CCTCCTTGCGGTAGAACA \\
Streptococcus bovis & TTCCTAGAGATAGGAAGTTTCTTCGG & ATGATGGCAACTAACAATAGGGGT \\
Ruminobacter amylophilus & CTGGGGAGCTGCCTGAAT & CATCTGAATGCGACTGGTTG \\
Succinimonas amylolytica & CGTTGGGCGGTCATTTGAAAC & CCTGAGCGTCAGTTACTATCCAGA \\
\hline
\end{tabular}

${ }^{1}$ Primers of general bacteria, Fibrobacter succinogenes, and Ruminococcus flavefaciens referred to in McSweeney and Denman (2007); Ruminococcus albus referred to in Wang et al. (1997); Succinimonas amylolytica and Streptococcus bovis referred to in Stevenson and Weimer (2007); Succinimonas amylolytica referred to in Khafipour et al. (2009b). 
(A3306, Sigma-Aldrich, St. Louis, MO) and sodium sulfite, and was expressed free of ash. For protein supplements, the residual $\mathrm{CP}$ in the bag was determined according to Kjeldahl method (976.05; AOAC, 1990).

\section{Calculation and Statistical Analyses}

Variables of in situ degradation kinetics of nutrients (DM and starch for grains; DM and NDF for forages) were estimated using the NLIN procedure of SAS (SAS Institute, 1999) according to the following model (Ørskov and McDonald, 1979):

$$
D t=a+b \times[1-\exp (-c t)]
$$

where $D t=$ degraded proportion at time $t ; a=$ the fraction that immediately disappears from the bag; $b=$ the fraction that is potentially degradable over time; $c$ $=$ constant rate of degradation of fraction $b\left(\mathrm{~h}^{-1}\right)$; and $t$ $=$ incubation time $(\mathrm{h})$. Effective ruminal degradability (ERD) was determined by

$$
\mathrm{ERD}=a+b \times c /(c+k p),
$$

where $a, b$, and $c$ are the degradation constants as described and $k p$ is the passage rate $\left(0.04 \mathrm{~h}^{-1}\right.$ for roughages and $0.06 \mathrm{~h}^{-1}$ for grains; Offner et al., 2003).

The duplicate in situ degradation data at each sample point of each goat in every period were averaged. The data of bacteria abundance used for the statistical analysis were $\log 10$-transformed to normalize their distribution. Data of ruminal pH, DMI, and in situ degradation parameters were analyzed using the MIXED model of SAS (SAS Institute, 1999) according to the following statistical model (Goiri et al., 2010):

$$
Y_{i j k}=\mu+S_{i}+T_{j}+P_{k}+\varepsilon_{i j k},
$$

where $Y_{i j k}=$ represents the dependent variable; $\mu=$ overall mean; $S_{i}=$ effect of the $i$ th sequence of treatments $(i=\mathrm{AB}, \mathrm{BA}) ; T_{j}=$ effect of the $j$ th treatment $\left(j=\right.$ control, SARA); $P_{k}=$ the effect of the $k$ th period $(k=1,2) ; \varepsilon_{i j k}=$ the residual error. For analysis of the repeated measurement data (VFA and bacteria), sampling time was added to the previous model with random (goat) and repeated statements (sampling time). In the repeated measures statistical analyses of variables, data were subjected to 3 covariance structures: unstructured, compound symmetric, and autoregressive order 1 covariance. The most desirable covariance structure was determined according to the smallest Schwarz's Bayesian criterion (Littell et al., 1998). Significance was declared at $P \leq 0.05$; trends were discussed at $P \leq 0.10$.

\section{RESULTS}

The sequence or the experimental period had no effect on any of the measurements $(P>0.50)$ and is not presented in the tables.

\section{Feed Intake, Ruminal $\mathrm{pH}$, and Bacteria Abundance}

The DMI was not affected by treatments $(1380 \mathrm{~g} / \mathrm{d}$; $P=0.574$, Table 4). Induction of SARA decreased average daily ruminal $\mathrm{pH}(P=0.047)$ and increased duration and area of ruminal pH below 5.8 or $5.6(P<$ 0.05). The SARA increased concentration of total VFA $(P=0.010)$ and the molar proportions of propionate $(P$ $=0.004)$. The acetate proportion $(P=0.013)$ and the acetate-to-propionate ratio $(P=0.001)$ were decreased during SARA. The molar ratios of butyrate, isobutyrate, valerate, and isovalerate were not influenced by treatment $(P>0.05)$. Compared with the control group, SARA reduced ruminal relative abundance of $F$. succinogenes and $R c$. flavefaciens $(P<0.05)$, and increased that of $S$. amylolytica and $R b$. amylophilus $(P$ $<0.05)$. However, the abundance of $R c$. albus and $S$. bovis were not affected by SARA $(P>0.05)$.

\section{In Situ Degradability}

Induction of SARA reduced 24- and 48-h DM and NDF degradabilities of corn silage (Table 5). The 48-h degradabilities of DM $(P=0.214)$ and $\operatorname{NDF}(P=$ $0.094)$ in alfalfa hay were not affected by SARA, but the 24 -h DM $(P=0.054)$ and NDF $(P=0.047$; Table $5)$ degradabilities tended to be reduced. Compared with the control group, SARA also decreased ERD of DM and NDF of alfalfa hay and corn silage $(P<0.05)$.

In situ degradability parameters $(a, b, c)$ and ERD of DM and starch of wheat were not affected by treatment $(P>0.05$; Table 6$)$. The degradability rates of DM $(P$ $=0.060)$ and starch $(P=0.040)$ of corn increased during SARA, but did not affect the ERD $(P>0.05)$. The SARA decreased 12-h in situ DM and CP disappearance values of soybean meal $(P=0.011)$ and extruded soy $(P=0.001)$, but did not affect the degradation of the other protein supplements $(P>0.05$; Table 7$)$.

\section{DISCUSSION}

Ruminal $\mathrm{pH}$ and its daily fluctuation characteristics are important factors in the regulation of microbial activity and the occurrence of SARA (Plaizier et al., 2008; Lechartier and Peyraud, 2011). Diet with $35 \%$ cracked wheat instead of corn (DM basis) resulted in an average duration of ruminal $\mathrm{pH}$ below 5.6 for more than $180 \mathrm{~min} / \mathrm{d}$, which can be considered as SARA in 
Table 4. Effect of SARA on DMI, rumen fermentation, and relative abundance of ruminal bacteria

\begin{tabular}{lcccc}
\hline Item & Control & SARA & SEM & $P$-value \\
\hline $\mathrm{DMI}, \mathrm{g} / \mathrm{d}$ & 1,358 & 1,402 & 26.4 & 0.57 \\
$\mathrm{pH}$ & & & & \\
Mean & 6.21 & 5.98 & 0.028 & 0.047 \\
Area under $\mathrm{pH} 5.8, \mathrm{pH} \times \mathrm{h} / \mathrm{d}$ & 0.44 & 1.95 & 0.411 & 0.001 \\
Area under $\mathrm{pH} 5.6, \mathrm{pH} \times \mathrm{h} / \mathrm{d}$ & 0.12 & 0.78 & 0.127 & 0.038 \\
$\mathrm{pH}<5.8, \mathrm{~h} / \mathrm{d}$ & 3.11 & 9.85 & 1.443 & 0.003 \\
$\mathrm{pH}<5.6, \mathrm{~h} / \mathrm{d}$ & 1.13 & 4.72 & 1.136 & 0.012 \\
Total VFA, mM & 105.0 & 123.8 & 4.20 & 0.010 \\
VFA, mol/100 mol & & & & \\
Acetate (A) & 62.8 & 56.6 & 1.33 & 0.013 \\
Propionate (P) & 18.0 & 20.2 & 0.47 & 0.004 \\
Butyrate & 13.7 & 14.3 & 0.21 & 0.15 \\
Isobutyrate & 2.4 & 3.1 & 0.21 & 0.15 \\
Valerate & 3.5 & 2.8 & 0.41 & 0.062 \\
Isovalerate & 3.1 & 3.2 & 0.30 & 0.69 \\
A:P ratio & 3.5 & 2.8 & 0.14 & 0.001 \\
Rumen bacteria, \% of 16S rRNA & & & & \\
Fibrobacter succinogenes & 0.939 & 0.382 & 0.1091 & 0.001 \\
Ruminococcus albus & 0.489 & 0.435 & 0.0854 & 0.58 \\
Ruminococcus flavefaciens & 0.484 & 0.153 & 0.1285 & 0.022 \\
Streptococcus bovis & 0.007 & 0.009 & 0.0022 & 0.74 \\
Succinimonas amylolytica & 0.157 & 0.468 & 0.1117 & 0.001 \\
Ruminobacter amylophilus & 0.330 & 0.743 & 0.1803 & 0.038 \\
\hline
\end{tabular}

ruminants (Gozho et al., 2005; Khafipour et al., 2009a). Previous studies also reported that substitution of dietary wheat or barley for corn decreased the ruminal
pH (Desnoyers et al., 2008, Leddin et al., 2009), which was attributed to the higher degradability of starch in wheat (Offner et al., 2003). The concentration of total

Table 5. Effect of SARA on in situ degradation of DM and NDF in alfalfa hay and corn silage

\begin{tabular}{|c|c|c|c|c|}
\hline Item $^{1}$ & Control & SARA & SEM & $P$-value \\
\hline \multicolumn{5}{|l|}{ Alfalfa hay, \% } \\
\hline \multicolumn{5}{|l|}{ DM } \\
\hline$a$ & 18.0 & 18.3 & 1.57 & 0.80 \\
\hline$b$ & 35.6 & 32.7 & 1.23 & 0.33 \\
\hline$c, \% / \mathrm{h}$ & 9.1 & 4.7 & 0.83 & 0.065 \\
\hline ERD & 42.7 & 35.6 & 1.35 & 0.009 \\
\hline 24-h degradability & 49.6 & 46.3 & 1.08 & 0.054 \\
\hline 48-h degradability & 51.0 & 48.2 & 1.64 & 0.21 \\
\hline \multicolumn{5}{|l|}{ NDF } \\
\hline$a$ & 13.3 & 12.8 & 1.10 & 0.12 \\
\hline$b$ & 36.8 & 32.4 & 0.75 & 0.001 \\
\hline$c, \% / \mathrm{h}$ & 7.8 & 5.0 & 0.59 & 0.024 \\
\hline ERD & 35.3 & 31.3 & 0.96 & 0.025 \\
\hline 24-h degradability & 37.8 & 33.2 & 2.61 & 0.047 \\
\hline 48-h degradability & 40.3 & 36.0 & 5.74 & 0.094 \\
\hline \multicolumn{5}{|l|}{ Corn silage, $\%$} \\
\hline \multicolumn{5}{|l|}{ DM } \\
\hline$a$ & 21.1 & 22.7 & 3.54 & 0.63 \\
\hline$b$ & 53.6 & 46.1 & 3.66 & 0.041 \\
\hline$c, \% / \mathrm{h}$ & 6.8 & 4.9 & 0.47 & 0.037 \\
\hline ERD & 54.8 & 48.1 & 1.79 & 0.007 \\
\hline 24-h degradability & 59.8 & 51.6 & 1.65 & 0.002 \\
\hline 48-h degradability & 69.8 & 59.3 & 2.18 & 0.014 \\
\hline \multicolumn{5}{|l|}{ NDF } \\
\hline$a$ & 14.0 & 16.0 & 2.74 & 0.45 \\
\hline$b$ & 69.4 & 53.0 & 3.86 & 0.039 \\
\hline$c, \% / \mathrm{h}$ & 6.5 & 4.2 & 0.75 & 0.027 \\
\hline $\mathrm{ERD}$ & 57.0 & 43.0 & 1.66 & 0.006 \\
\hline 24-h degradability & 57.1 & 42.4 & 2.68 & 0.001 \\
\hline 48-h degradability & 68.2 & 55.5 & 2.91 & 0.026 \\
\hline
\end{tabular}


LI ET AL.

Table 6. Effect of SARA on in situ degradation of DM and starch in wheat and corn

\begin{tabular}{lcccc}
\hline Item $^{1}$ & Control & SARA & SEM & $P$-value \\
\hline Wheat, $\%$ & & & & \\
DM & & & & \\
$a$ & 66.4 & 58.9 & 5.84 & 0.68 \\
$b$ & 27.9 & 34.0 & 5.34 & 0.75 \\
$c, \% / \mathrm{h}$ & 22.0 & 38.1 & 6.67 & 0.28 \\
ERD & 88.4 & 88.3 & 0.41 & 0.81 \\
Starch & & & & \\
$a$ & 69.2 & 64.3 & 2.23 & 0.37 \\
$b$ & 25.5 & 29.8 & 8.05 & 0.37 \\
$c, \% / \mathrm{h}$ & 43.2 & 57.5 & 9.94 & 0.53 \\
ERD & 91.6 & 91.1 & 0.33 & 0.65 \\
Corn, $\%$ & & & & \\
DM & 31.6 & 21.8 & 3.01 & 0.045 \\
$a$ & 64.1 & 74.0 & 3.52 & 0.052 \\
$b$ & 7.7 & 10.7 & 2.16 & 0.060 \\
$c, \% / \mathrm{h}$ & 67.7 & 69.3 & 1.44 & 0.87 \\
ERD & & & & \\
Starch & 26.4 & 14.4 & 3.00 & 0.025 \\
$a$ & 76.9 & 87.5 & 3.21 & 0.063 \\
$b$ & 9.5 & 13.3 & 0.86 & 0.040 \\
$c, \% / \mathrm{h}$ & 73.6 & 74.7 & 0.83 & 0.38 \\
ERD & & & & \\
\hline
\end{tabular}

${ }^{1} a=$ rapidly degradable fraction, $b=$ slowly degradable fraction, $c=$ constant rate of degradation of fraction $b$; ERD (effective ruminal degradability) $=a+b \times c /(c+k p)$, where $k p$ is the passage rate of concentrate $\left(0.06 \mathrm{~h}^{-1}\right)$.

VFA and the molar proportion of propionate increased during SARA, which indicated that more starch was fermented in the rumen compared with the control group.

In the current study, induction of SARA in dairy goats increased some amylolytic ( $R b$. amylophilus and S. amylolytica) and reduced cellulolytic species (F. succinogenes and $R c$. flavefaciens) in the rumen. The shift of these bacteria during SARA was the result of the low ruminal $\mathrm{pH}$ and high ruminal degradable starch. Several experiments also observed that rumen cellulolytic species dramatically decreased under low ruminal $\mathrm{pH}$ when animals received highly fermentable carbohydrate diets (Khafipour et al., 2009b; Petri et al., 2012; Metzler-Zebeli et al., 2013). Because Rb. amylophilus and $S$. amylolytica can use $\alpha$-linked glucose molecules (i.e., maltose, dextrin, and starch) as fermentable substrates, ruminants receiving high-starch diet can stimulate these species proliferation (Goad et al., 1998; Petri et al., 2012). However, Khafipour et al. (2009b) observed that high dietary grain-induced SARA did not affect or even reduced $R b$. amylophilus and $S$. amylolytica and increased $S$. bovis (lactate producer) in the rumen. This discrepancy might be related to the severity of SARA, as the low ruminal $\mathrm{pH}(5.62 \mathrm{~h} / \mathrm{d}$ below $\mathrm{pH}<5.6)$ is also unfavorable for the survival of these bacteria (Hook et

Table 7. In situ 12-h DM and CP disappearance values of plant protein supplements

\begin{tabular}{|c|c|c|c|c|}
\hline Item $^{1}$ & Control & SARA & SEM & $P$-value \\
\hline \multicolumn{5}{|l|}{ DM disappearance value, $\%$} \\
\hline Corn gluten meal & 41.6 & 44.5 & 2.63 & 0.19 \\
\hline Cottonseed meal & 57.6 & 55.2 & 1.05 & 0.17 \\
\hline Dried distillers grains with solubles & 53.2 & 53.7 & 2.64 & 0.84 \\
\hline Extruded soybean & 76.2 & 68.4 & 2.72 & 0.002 \\
\hline Rapeseed meal & 56.0 & 60.3 & 2.29 & 0.34 \\
\hline Soybean meal & 78.3 & 67.2 & 3.33 & 0.001 \\
\hline Wheat germ meal & 95.7 & 95.2 & 0.32 & 0.28 \\
\hline \multicolumn{5}{|l|}{$\mathrm{CP}$ disappearance value, $\%$} \\
\hline Corn gluten meal & 30.8 & 34.2 & 2.59 & 0.16 \\
\hline Cottonseed meal & 62.9 & 58.6 & 2.43 & 0.11 \\
\hline Dried distillers grains with solubles & 37.2 & 39.8 & 4.71 & 0.60 \\
\hline Extruded soybean & 63.9 & 51.8 & 4.16 & 0.001 \\
\hline Rapeseed meal & 58.5 & 59.6 & 2.77 & 0.77 \\
\hline Soybean meal & 72.2 & 57.9 & 4.02 & 0.011 \\
\hline Wheat germ meal & 96.9 & 96.6 & 0.44 & 0.65 \\
\hline
\end{tabular}


al., 2011). In the present study, ruminal S. bovis abundance was low and not affected by SARA. This result is in accordance with previous studies during experimentally grain-induced SARA (Fernando et al., 2010; Petri et al., 2012).

As expected, the SARA decreased in situ roughages degradabilities of DM and NDF, which might be attributed to the decline of ruminal cellulolytic bacteria ( $F$. succinogenes and Rc. flavefaciens). Similarly, Plaizier et al. (2001) observed that SARA reduced in situ DM and NDF degradabilities of mixed hay (alfalfa and grass hay) in dairy cows. Krajcarski-Hunt et al. (2002) also found that induction of SARA by increasing dietary wheat or barley pellets ( $25 \%$ of DM in TMR) decreased in situ NDF degradabilities of grass hay, legume hay, and corn silage. The SARA did not affect the 48-h DM $(49.6 \%)$ and NDF $(38.2 \%)$ disappearance values of alfalfa hay, although this challenge reduced these parameters in corn silage $(-15$ and $-19 \%$ for DM and NDF, respectively). This discrepancy might be due to the different potential degradation degradability (sum of rapidly degradable fraction and slowly degradable fraction) of the 2 roughages. Alfalfa hay had lower potential degradation fractions of DM (52.3 vs. $71.8 \%)$ and NDF (47.7 vs. $76.2 \%$ ) than corn silage in our study. Because of the low amount of available DM and NDF in alfalfa hay, the time to reach degradation kinetics plateau was shortened, and resulted in similar degradabilities at $48 \mathrm{~h}$. These results suggested that SARA was successfully induced by increasing dietary cracked wheat to $35 \%$ in dairy goats, which led to a reduction in fiber degradability and ruminal cellulolytic bacteria (F. succinogenes and Rc. flavefaciens).

The ERD of starch in wheat and corn was not affected by treatment, although SARA increased the abundance of $S$. amylolytica and $R b$. amylophilus. The rate and extent of starch degradation in the rumen mainly depends on rumen microorganisms, grain type, processing method, and rumen passage rate (Svihus et al., 2005; Huntington et al., 2006). Data on the effects of ruminal $\mathrm{pH}$ or SARA on starch in situ degradation is limited. Several experiments observed that an increased dietary grain content increased ruminal amylase activity in vivo and in vitro (Jouany and Martin, 1997; Martínez et al., 2010). Induction of SARA in our study accelerated the starch degradability rate of corn (9.5 vs. $13.3 \% / \mathrm{h}$ ), which might be attributed to the high abundance of ruminal amylolytic bacteria. However, the in situ degradation rate of starch in wheat was not affected by diets $(50.4 \% / \mathrm{h})$. Rumen bacteria more easily digest starch in wheat than that in corn because of the different endosperm types (floury endosperm vs. vitreous endosperm; Allen, 2012). Ljøkjel et al. (2003) found that neither pelleting nor expanding had significant effects on the in situ degradation of starch in wheat and barley, which can be explained by the very high degradability before processing (Svihus et al., 2005). Thus, lack of significant effects of SARA on degradability of starch in wheat might due to its high ruminal degradability.

For plant protein supplements, the 12-h incubation was adopted because this length represents the residue that escapes ruminal degradation (Gargallo et al., 2006). In the present study, SARA reduced DM and CP 12-h in situ disappearance values of soybean meal $(-19.8 \%)$ and extruded soybean $(-18.9 \%)$. Previous studies indicated that plant protein supplements have higher degradability in high-roughage diets than in high-concentrate diets (Loerch et al. 1983; Molero et al. 2004). Molero et al. (2004) observed that heifers receiving high-concentrate diets reduced ERD of soybean meal $(-6.5 \%)$, corn gluten feed $(-10.2 \%)$, and fish meal $(-6.9 \%)$ compared with those receiving lowconcentrate diets. Kohn and Allen (1995) also found that CP degradability increased with the addition of cellulases in vitro. Plant proteins are integrated within the cellulose tridimensional structure, which must be broken down by polysaccharide enzymes (e.g., cellulase and hemicellulase) of ruminal bacteria to allow proteolysis (Wallace et al., 1997; Bach et al., 2005; Rotger et al. 2006). In the current study, it is possible that SARA decreased ruminal cellulolytic activity and led to a reduction in the degradation rate of protein (soybean meal and extruded soy) due to the limitation of the access of proteases to their target.

In the present study, however, the CP disappearance of the other protein supplements was not decreased during SARA. Loerch et al. (1983) also observed that the in situ degradability of CP in corn gluten meal was not affected by increasing dietary high-moisture corn from 20 to $80 \%$ (ruminal $\mathrm{pH}$ from 6.55 to 5.75 ), although the CP degradation of soybean meal $(-31.2 \%)$ and dehydrated alfalfa $(-50.7 \%)$ were dramatically reduced. The degradation rate of protein supplements in rumen mainly depends on their structure (fiber-bound protein, susceptibility, and accessibility of peptide bonds; Bach et al., 2005) and the proteolytic activity of ruminal microflora. Therefore, the different $\mathrm{CP}$ disappearance among plant protein supplements in response to SARA may be attributed to their different protein to fiber structure.

\section{CONCLUSIONS}

The results of the present study indicate that the cracked wheat-induced SARA affected starch (corn) and CP (soybean meal and extruded soy) degradation in the rumen. This effect depended on the structure 
of the feed and the ruminal microbiota (i.e., increases in $R b$. amylophilus and $S$. amylolytica and decreases in F. succinogenes and $R c$. flavefaciens). Future feed evaluation systems need to consider the changes in the degradability of starch and protein in diets when the animal is at risk of SARA.

\section{ACKNOWLEDGMENTS}

The research was supported by the National Key Technologies R\&D Program of China (Beijing, China; 2012BAD12B02, 2012BAD39B05) and the Program of International S\&T Cooperation of China (Beijing, China; 2010DFB34230). The valuable suggestions and language help of Austin Cantor (University of Kentucky, Lexington) during the preparation of this manuscript is greatly appreciated.

\section{REFERENCES}

Allen, M. S. 2012. Adjusting concentration and ruminal digestibility of starch through lactation. Pages 24-30 in Proc. Four-State Dairy Nutr. Mgmt Conf. Dubuque, IA. Dept. Dairy Sci., Univ. Wisconsin, Madison.

AOAC. 1990. Official Methods of Analysis. 15th ed. Assoc. Off. Anal. Chem., Arlington, VA.

Bach, A., S. Calsamiglia, and M. D. Stern. 2005. Nitrogen metabolism in the rumen. J. Dairy Sci. 88:E9-E21.

Bannink, A., and S. Tamminga. 2005. Rumen function. Pages 263-288 in Quantitative Aspects of Ruminant Digestion and Metabolism. 2nd ed. J. Dijkstra, J. M. Forbes, and J. France, ed. CABI Publishing, Wallingford, UK

Denman, S. E., and C. S. McSweeney. 2005. PCR-based methods for analysis of populations and gene expression. 3.2 Quantitative (Real time) PCR. Pages 105-115 in Methods in Gut Microbial Ecology for Ruminants. H. Makkar and C. S. McSweeney, ed. Springer, Houten, the Netherlands.

Desnoyers, M., C. Duvaux-Ponter, K. Rigalma, S. Roussel, O. Martin and S. Giger-Reverdin. 2008. Effect of concentrate percentage on ruminal $\mathrm{pH}$ and time-budget in dairy goats. Animal 2:1802-1808.

Fernando, S. C., H. T. Purvis, F. Z. Najar, L. O. Sukharnikov, C. R. Krehbiel, T. G. Nagaraja, B. A. Roe, and U. DeSilva. 2010. Rumen microbial population dynamics during adaptation to a highgrain diet. Appl. Environ. Microbiol. 76:7482-7490.

Furchtenicht, J. E., and G. A. Broderick. 1987. Effect of inoculum preparation and dietary energy on microbial numbers and rumen protein degradation activity. J. Dairy Sci. 70:1404-1410.

Gargallo, S., S. Calsamiglia, and A. Ferret. 2006. Technical note: A modified three-step in vitro procedure to determine intestinal digestion of proteins. J. Anim. Sci. 84:2163-2167.

Goad, D. W., C. L. Goad, and T. G. Nagaraja. 1998. Ruminal microbial and fermentative changes associated with experimentally induced subacute acidosis in steers. J. Anim. Sci. 76:234-241.

Goiri, I., L. M. Oregui, and A. Garcia-Rodriguez. 2010. Use of chitosans to modulate ruminal fermentation of a 50:50 forage-to-concentrate diet in sheep. J. Anim. Sci. 88:749-755.

Gozho, G. N., J. C. Plaizier, D. O. Krause, A. D. Kennedy, and K. M. Wittenberg. 2005. Subacute ruminal acidosis induces ruminal lipopolysaccharide endotoxin release and triggers an inflammatory response. J. Dairy Sci. 88:1399-1403.

Hobson, P. N., R. J. Wallace, and M. P. Bryant. 1982. Microbial ecology and activities in the rumen: Part I. Crit. Rev. Microbiol. $9: 165-225$.

Hook, S. E., M. A. Steele, K. S. Northwood, J. Dijkstra, J. France, A. D. Wright, and B. W. McBride. 2011. Impact of subacute ruminal acidosis (SARA) adaptation and recovery on the density and diversity of bacteria in the rumen of dairy cows. FEMS Microbiol. Ecol. 78:275-284.

Hristov, A. N., T. A. McAllister, Z. Xu, and C. J. Newbold. 2002 Proteolytic activity in ruminal fluid from cattle fed two levels of barley grain: A comparison of three methods of determination. J. Sci. Food Agric. 82:1886-1893.

Huntington, G. B., D. L. Harmon, and C. J. Richards. 2006. Sites, rates, and limits of starch digestion and glucose metabolism in growing cattle. J. Anim. Sci. 84(Suppl.):E14-E24.

Jouany, J. P., and C. Martin. 1997. Effect of protozoa in plant cell wall and starch digestion in the rumen. Pages 11-24 in Rumen Microbes and Digestive Physiology in Ruminants. R. Onodera, H. Itabashi, K. Ushida, H. Yano, and Y. Sasaki, ed. Japan Societies Press, Kargar, Tokyo, Japan.

Khafipour, E., D. O. Krause, and J. C. Plaizier. 2009a. A grain-based subacute ruminal acidosis challenge causes translocation of lipopolysaccharide and triggers inflammation. J. Dairy Sci. 92:10601070.

Khafipour, E., S. Li, J. C. Plaizier, and D. O. Krause. 2009b. Rumen microbiome composition determined using two nutritional models of subacute ruminal acidosis. Appl. Environ. Microbiol. 75:7115-7124.

Kleen, J. L., and C. Cannizzo. 2012. Incidence, prevalence and impact of SARA in dairy herds. Anim. Feed Sci. Technol. 172:4-8.

Kohn, R. A., and M. S. Allen. 1995. In vitro protein degradation of feeds using concentrated enzymes extracted from rumen contents. Anim. Feed Sci. Technol. 52:15-28.

Krajcarski-Hunt, H., J. C. Plaizier, J. P. Walton, R. Spratt, and B. W. McBride. 2002. Short communication: Effect of subacute ruminal acidosis on in situ fiber digestion in lactating dairy cows. J. Dairy Sci. 85:570-573.

Lechartier, C., and J. L. Peyraud. 2011. The effects of starch and rapidly degradable dry matter from concentrate on ruminal digestion in dairy cows fed corn silage-based diets with fixed forage proportion. J. Dairy Sci. 94:2440-2454.

Leddin, C. M., C. R. Stockdale, J. Hill, J. W. Heard, and P. T. Doyle. 2009. Increasing amounts of crushed wheat fed with pasture hay reduced dietary fiber digestibility in lactating dairy cows. J. Dairy Sci. 92:2747-2757.

Littell, R. C., P. R. Henry, and C. B. Ammerman. 1998. Statistical analysis of repeated measures data using SAS procedures. J. Anim. Sci. 76:1216-1231.

Ljøkjel, K., A. Skrede, and O. Harstad. 2003. Effects of pelleting and expanding of vegetable feeds on in situ protein and starch digestion in dairy cows. J. Anim. Feed Sci. 12:435-449.

Loerch, S. C., L. L. Berger, D. Gianola, and G. C. Fahey. 1983. Effects of dietary protein source and energy level on in situ nitrogen disappearance of various protein sources. J. Anim. Sci. 56:206-216.

Martínez, M. E., M. J. Ranilla, M. L. Tejido, C. Saro, and M. D. Carro. 2010. Comparison of fermentation of diets of variable composition and microbial populations in the rumen of sheep and Rusitec fermenters. II. Protozoa population and diversity of bacterial communities. J. Dairy Sci. 93:3699-3712.

McAllister, T. A., H. D. Bae, G. A. Jones, and K. J. Cheng. 1994. Microbial attachment and feed digestion in the rumen. J. Anim. Sci. 72:3004-3018.

McSweeney, C. S., and S. E. Denman. 2007. Effect of sulfur supplements on cellulolytic rumen micro-organisms and microbial protein synthesis in cattle fed a high fibre diet. J. Appl. Microbiol. 103:1757-1765.

Metzler-Zebeli, B. U., S. Schmitz-Esser, F. Klevenhusen, L. Podstatzky-Lichtenstein, M. Wagner, and Q. Zebeli. 2013. Grain-rich diets differently alter ruminal and colonic abundance of microbial populations and lipopolysaccharide in goats. Anaerobe 20:65-73.

Molero, R., M. Ibars, S. Calsamiglia, A. Ferret, and R. Losa. 2004. Effects of a specific blend of essential oil compounds on dry matter and crude protein degradability in heifers fed diets with different forage to concentrate ratios. Anim. Feed Sci. Technol. 114:91-104. 
Offner, A., A. Bach, and D. Sauvant. 2003. Quantitative review of in situ starch degradation in the rumen. Anim. Feed Sci. Technol. 106:81-93.

Ørskov, E., and I. McDonald. 1979. The estimation of protein degradability in the rumen from incubation measurements weighted according to rate of passage. J. Agric. Sci. 92:499-503.

Petri, R. M., R. J. Forster, W. Yang, J. J. McKinnon, and T. A. McAllister. 2012. Characterization of rumen bacterial diversity and fermentation parameters in concentrate fed cattle with and without forage. J. Appl. Microbiol. 112:1152-1162.

Plaizier, J. C., J. Keunen, J. P. Walton, T. Duffield, and B. W. McBride. 2001. Effect of subacute ruminal acidosis on in situ digestion of mixed hay in lactating dairy cows. Can. J. Anim. Sci. $81: 421-423$.

Plaizier, J. C., D. O. Krause, G. N. Gozho, and B. W. McBride. 2008. Subacute ruminal acidosis in dairy cows: The physiological causes, incidence and consequences. Vet. J. 176:21-31.

Rotger, A., A. Ferret, S. Calsamiglia, and X. Manteca. 2006. In situ degradability of seven plant protein supplements in heifers fed high concentrate diets with different forage to concentrate ratio. Anim. Feed Sci. Technol. 125:73-87.

Russell, J. B., and D. B. Wilson. 1996. Why are ruminal cellulolytic bacteria unable to digest cellulose at low pH? J. Dairy Sci. 79:1503-1509.

SAS Institute. 1999. SAS User's Guide: Statistics. Version 8.01. SAS Institute Inc., Cary, NC.

Stevenson, D. M., and P. J. Weimer. 2007. Dominance of Prevotella and low abundance of classical ruminal bacterial species in the bovine rumen revealed by relative quantification real-time PCR Appl. Microbiol. Biotechnol. 75:165-174.
Svihus, B., A. K. Uhlen, and O. M. Harstad. 2005. Effect of starch granule structure, associated components and processing on nutritive value of cereal starch: A review. Anim. Feed Sci. Technol. 122:303-320.

Van Soest, P. J., J. B. Robertson, and B. A. Lewis. 1991. Methods for dietary fiber, neutral detergent fiber, and nonstarch polysaccharides in relation to animal nutrition. J. Dairy Sci. 74:3583-3597.

Wallace, R. J. 1996. The proteolytic systems of ruminal microorganisms. Ann. Zootech. 45:301-308.

Wallace, R. J., R. Onodera, and M. A. Cotta. 1997. Metabolism of nitrogen-containing compounds. Pages 283-328 in The Rumen Microbial Ecosystem. P. N. Hobson and C. S. Stewart, ed. Blackie Academic and Professional, London, UK.

Wang, R.-F., W.-W. Cao, and C. E. Cerniglia. 1997. PCR detection of Ruminococcus spp. in human and animal faecal samples. Mol. Cell. Probes 11:259-265.

Wang, Y., and T. A. McAllister. 2002. Rumen microbes, enzymes and feed digestion: A review. Asian-australas. J. Anim. Sci. 15:1659 1676.

Zhao, X. H., C. J. Liu, Y. Liu, C. Y. Li, and J. H. Yao. 2013. Effects of replacing dietary starch with neutral detergent-soluble fibre on ruminal fermentation, microbial synthesis and populations of ruminal cellulolytic bacteria using the rumen simulation technique (RUSITEC). J. Anim. Physiol. Anim. Nutr. (Berl.) 97:1161-1169.

Zhao, X. H., T. Zhang, M. Xu, and J. H. Yao. 2011. Effects of physically effective fiber on chewing activity, ruminal fermentation, and digestibility in goats. J. Anim. Sci. 89:501-509. 